DOI: https://doi.org/10.30525/978-9934-26-108-4-12

Olha Golikova

Junior Researcher at Economic Nature Use

Management Regulation Department

Institute of Market Problems and Economic and Ecological Researches

of National Academy of Sciences of Ukraine

\title{
INSTITUTIONAL PRECONDITIONS FOR DIVERSIFICATION ENSURING OF THE NATURAL RECREATIONAL RESOURCES AND TERRITORIES USE ${ }^{1}$
}

\begin{abstract}
Summary
The need to diversify the use of natural recreational resources and territories is a national issue of environmental management at the national and regional entities. This is especially true for unique natural areas and objects. The paper analyzes the current state and identifies trends in the development of recreational and tourist sphere of Ukraine. The analysis of normative-legal and organizational support of processes of of natural resources and territories use is carried out. It is established that a separate part of the main factors of production (facilities and fixed assets involved in the provision of health services) are privately owned by business entities, as natural recreational resources are owned by the state and local executive authorities. This situation is due to the need to reconcile socio-economic and environmental interests. The need to improve the permitting system for assessing natural resource potential, in particular natural recreational resources, as a tool for state regulation of economic relations on forms and property rights to natural recreational and involvement of socio-economic interests of territorial development and recreational tourism.
\end{abstract}

\section{Вступ}

Природні ресурси є основним чинником суспільного виробництва, що суттєво впливає на сучасний стан економічної системи будь-якого рівня, ïx використання впливає на рівень національної безпеки та визначає стратегічний потенціал розвитку держави на перспективу. Дотримуючись цього, світова спільнота вибудовує нові моделі суспільного диверсифікованого розвитку, а саме: сталий розвиток, «зелена» та «циркулярна» економіка, кліматична програма тощо. Серед найбільш уразливих природних ресурсів $є$ рекреаційні ресурси, адже вони альтернативні за своїм використанням, знаходяться на територіях,

\footnotetext{
${ }^{1}$ Підготовлено в межах гранту НАН України для молодих вчених «Формування та використання природноресурсних активів рекреаційно-туристичної сфери» (КПКВК 6541230 «Підтримка розвитку пріоритетних напрямів наукових досліджень», РК №0120U100159).
} 
які в егоїстичних пріоритетах сьогодення можуть використовуватися у будівельних, промислових, сільськогосподарських та інших цілях.

Сучасна система надання дозволів на видобування корисних копалин регламентує технологічні, організаційні та кількісні вимоги щодо використання природних рекреаційних ресурсів. Проте поза увагою дозвільних органів залишаються питання надання користувачем родовища (суб'єктом господарської діяльності) інформації щодо економічних показників використання рекреаційних ресурсів та якісного стану об'єктів природокористування.

\section{Розділ 1. Сучасні тенденції розвитку рекреаційно-туристичної сфери України}

Туризм та рекреація відносяться до сфер діяльності, які стрімко розвиваються. На це впливають такі чинники, як висока прибутковість рекреаційно-туристичної діяльності, інвестиційна привабливість, можливість отримання валютних надходжень, низький рівень інвестицій за започаткування діяльності, невеликі витрати на створення нових робочих місць, зростання потреб у відновлення здоров'я, життєвих сил, фізичного, психоемоційного, культурного розвитку. Тому з'являються нові види послуг та атракції, які базуються як на традиційних функціях цих сфер, так і в контексті формування економіки вражень, «зеленої» економіки, поведінкової економіки, інклюзивного розвитку.

Розглянемо кількісні показники рекреаційно-туристичної сфери. За період із 2015 по 2019 р. загальна кількість суб'єктів туристичної діяльності зросла на 4,39 \%, однак порівняно з 2014 р. впала на 17\%. Що стосується туроператорів та турагентів, то за період із 2015 по 2019 р. їх кількість в Україні також має позитивну динаміку, а саме збільшення на 7,6\% - туроператорів, на 2,2\% - турагентів. Однак порівняно з 2014 p. прослідковується така сама тенденція до зменшення: на 19,3\% у туроператорів, на $15,1 \%$ - у турагентів. У табл. 1 відображено дані щодо розподілу туристів, обслугованих туроператорами та турагентами, за метою поїздки. Вони свідчать, що 93\% від усіх обслужених припадає на дозвілля та відпочинок. Загальна кількість туристів у 2019 p. становила 5319952 особи, що свідчить про збільшення майже на 58\% порівняно з 2014 p. (2 216957 осіб), у тому числі: кількість подорожуючих із метою навчання, ділових та службових поїздок збільшилася на $44 \%$; обсяг подорожей із метою дозвілля за період із 2014 по 2019 р. збільшився приблизно на 59\%; кількість споживачів подорожей із лікувальною метою збільшилася майже на $57 \%$; кількість подорожуючих, метою яких є спортивний туризм, збільшилася на 42\%; кількість подорожуючих із метою отримання послуг спеціалізованого туризму з 2014 по 2019 р. зросла приблизно на 98\%. 
Таблиця 1

Розподіл туристів, обслугованих туроператорами та турагентами, за метою поїздки, тис осіб

\begin{tabular}{|l|c|c|c|c|c|c|}
\hline Показники & $\mathbf{2 0 1 4}$ & $\mathbf{2 0 1 5}$ & $\mathbf{2 0 1 6}$ & $\mathbf{2 0 1 7}$ & $\mathbf{2 0 1 8}$ & $\mathbf{2 0 1 9}$ \\
\hline $\begin{array}{l}\text { Розподіл туристів, } \\
\text { обслугованих туроператорами } \\
\text { та турагентами, усього }\end{array}$ & 2216,9 & 1814,8 & 2250,1 & 2403,9 & 3957,6 & 5319,9 \\
\hline службова, ділова, навчання & 147,5 & 178,8 & 176,2 & 194,9 & 211,8 & 267,5 \\
\hline дозвілля, відпочинок & 2033,0 & 1510,7 & 1902,9 & 2143,6 & 3671,4 & 4963,9 \\
\hline лікування & 23,9 & 29,9 & 79,4 & 54,7 & 61,3 & 55,9 \\
\hline спортивний туризм & 2,3 & 2,1 & 2,9 & 2,6 & 3,3 & 3,9 \\
\hline спеціалізований туризм & 0,3 & 1,2 & 0,8 & 1,8 & 1,8 & 21,3 \\
\hline
\end{tabular}

Джерело: побудовано за даними [1]

Відповідно до даних Державної служби статистики, обсяги обслуговування туристів за видами туризму з 2014 по 2019 р. свідчить про ріст туристичного руху в Україні, загальна кількість туристів зросла на 3102995 осіб, що становить відповідно 58\%, із них: кількісні показники іноземних туристів збільшилися майже на $80 \%$; обсяги виїзних туристів - на 59\%, внутрішніх - на $38 \%$. Водночас найбільший хвильовий показник в"їзних (іноземних) та виїзних туристів був зафіксований у 2018 р. порівняно з 2014-2017 рр.: 72941 та 3508113 осіб відповідно.

Кількісні показники санаторіїв та пансіонатів із лікуванням у період із 2014 по 2019 р. (табл. 2) суттєво зменшилися: із 320 од. у 2014 р. до 244 од. у 2018 р., що становить майже 23\%, утім, декларована кількість ліжок для відпочиваючих майже не скоротилася: 79 тис од. - у 2014 р., 71 тис од. - у 2017 р., 79 тис од. - у 2018 р.

Таблиця 2

\section{Динаміка показників санаторно-курортних}

та оздоровчих закладів України

\begin{tabular}{|l|c|c|c|c|c|}
\hline \multicolumn{1}{|c|}{ Показники } & $\mathbf{2 0 1 4}$ & $\mathbf{2 0 1 5}$ & $\mathbf{2 0 1 6}$ & $\mathbf{2 0 1 7}$ & $\mathbf{2 0 1 8}$ \\
\hline Санаторії та пансіонати з лікуванням & 320 & 309 & 291 & 284 & 244 \\
\hline у них ліжок, одиниць & 79 & 78 & 70 & 71 & 79 \\
\hline Санаторії-профілакторії & 118 & 79 & 63 & 55 & 55 \\
\hline у них ліжок, тис одиниць & 17 & 17 & 12 & 10 & 11 \\
\hline Будинки і пансіонати відпочинку & 90 & 76 & 73 & 67 & 66 \\
\hline у них місць, тис одиниць & 17 & 15 & 14 & 12 & 13 \\
\hline Бази та інші заклади відпочинку & 1400 & 1399 & 1295 & 1235 & 1245 \\
\hline у них місць, тис одиниць & 157 & 165 & 146 & 133 & 140 \\
\hline Дитячі оздоровчі табори & 13977 & 9743 & 9669 & 9745 & 9802 \\
\hline у них місць, тис одиниць & 126 & 113 & 112 & 106 & 114 \\
\hline
\end{tabular}

Джерело: побудовано за даними [1] 
Негативні показники динаміки розвитку притаманні також санаторіямпрофілакторіям, їх чисельність скоротилася зі 188 од. у 2014 р. до 55 од. у 2018 р., що становить майже 70\%, утім, на кількість місць це вплинуло не так суттєво: 17 тис од. - у 2017 р. та 11 тис од. - у 2018 р. Кількість баз, дитячих оздоровчих таборів будинків та пансіонатів відпочинку також зменшилася.

Динаміка обслуговування рекреантів за період із 2014 по 2018 р. була негативною: у санаторіях та пансіонатах із лікуванням - майже на $60 \%$; у санаторіях-профілакторіях - на 54\%; у будинках і пансіонатах відпочинку - майже на $82 \%$; на базах та інших закладах відпочинку приблизно на 24\%; у дитячих оздоровчих таборах - на 21\% (табл. 3 ).

Таблиця 3

Динаміка обслуговуваних осіб у санаторно-курортних

та оздоровчих закладах за 2014-2018 рр., тис осіб

\begin{tabular}{|l|c|c|c|c|c|}
\hline \multicolumn{1}{|c|}{ Показники } & $\mathbf{2 0 1 4}$ & $\mathbf{2 0 1 5}$ & $\mathbf{2 0 1 6}$ & $\mathbf{2 0 1 7}$ & $\mathbf{2 0 1 8}$ \\
\hline Санаторії та пансіонати з лікуванням & 1249 & 670 & 544 & 449,550 & 499 \\
\hline Санаторії-профілакторії & 130 & 100 & 61 & 59,801 & 58,989 \\
\hline Будинки і пансіонати відпочинку & 361 & 81 & 77 & 65,459 & 65 \\
\hline Бази та інші заклади відпочинку & 1018 & 738 & 785 & 774,178 & 773 \\
\hline Дитячі оздоровчі табори & 219 & 125 & 109 & 115,923 & 172 \\
\hline
\end{tabular}

Джерело: побудовано за даними [1]

Чинники, які впливають на формування суспільних потреб, можна умовно поділити на: 1) соціально-економічні: соціальна структура населення, зайнятість, співвідношення міського та сільського населення, доходи та витрати населення, диференціація життєвого рівня населення, рівень стратифікації суспільства, зміна форм та прав власності; 2) медико-біологічні: стан здоров'я і психофізіологічні особливості населення; 3) природні та екологічні: природні умови, в яких проживає людина, екологічна ситуація, територіальний розподіл рекреаційних ресурсів та віддаленість від місць проживання тощо.

Відповідно до змісту зазначених чинників впливу на формування суспільних рекреаційно-туристичних потреб та публікацій науковців [2-19], виявлено такі тенденції розвитку рекреаційно-туристичної сфери України:

- динамічність розвитку галузі світового господарства та стратегічний напрям більшості регіонів України, що забезпечує створення нових робочих місць, активізацію інвестицій, поповнення місцевих бюджетів, сприяє розвитку супутніх видів економічної діяльності тощо. Сучасні вимоги до розвитку рекреаційно-туристичної сфери диктують певний стиль взаємовідносин соціо-економіко-екологічної системи, безпосередньо залучаючи до програм заходів екологічний аспект, вимагаючи розглядати можливість проведення диверсифікації 
використання природних рекреаційних ресурсів та поліпшення екологічного стану територій;

- погіршення здоров'я населення та підвищення ступеню ризиків виявлення окремих хвороб, причинами чого стали відповідні умови та спосіб життя, стан навколишнього середовища, порушення вимог до умов праці та іiі інтенсивності (незначні позиції сфери оздоровлення у структурі національного виробництва);

- низький рівень доходів серед значного відсотка населення через активну стратифікацію суспільства за цим фактором призводить до конфлікту очікувань між бажаннями, нагальними потребами i можливостями населення, що, своєю чергою, має наслідком погіршення стану здоров`я населення. Тобто тенденція щодо реалізації запитів людей із низьким та середнім рівнями доходів вимагає розвивати сферу рекреації i туризму, зокрема використовуючи диверсифікацію використання природних ресурсів та рекреаційних умов в рекреаційнотуристичній сфері з урахуванням інклюзивності;

- порушення балансу урбанізованих міських та рекреаційних територій через збільшення ступеню урбанізації, зростання чисельності міського населення, зменшення безпечного життєвого простору;

- удосконалення технологій та умов праці, підвищення кваліфікаційних вимог до співробітників призводять до надмірних психофізичних, психоемоційних навантажень. Тобто відбувається зростання попиту на реабілітацію, рекреацію та профілактику професійних захворювань;

- розширення рекреаційних попиту і пропозиції, які складаються 3 активного способу життя, реалізації креативних навичок, фізичних здібностей, міжособистісного спілкування, сприяння духовного розвитку шляхом розвитку аспекту вражень рекреаційного природокористування [18];

- антропогенний вплив на стан природного середовища. Такі параметри рекреаційної сфери, як екологічно чисте довкілля, збереження ділянок первісної природи, біорізноманіття природних ландшафтів, зумовлюють екологічний пріоритет i територіальну ідентифікацію суб єктів рекреаційного природокористування;

- природно-ресурсна орієнтація рекреаційно-туристичної сфери характеризується такими негативними явищами, як неефективне використання спеціальних природних рекреаційних ресурсів та їх вичерпання, деградація особливо цінних ландшафтів, їх біорізноманіття, замученість рекреаційних ресурсів у суміжних сферах діяльності тощо;

- значна частина основних факторів рекреаційного виробництва знаходиться у приватній власності суб єктів економічної діяльності, тоді як природні рекреаційні ресурси знаходяться у власності держави. Цим зумовлено виникнення соціо-економіко-екологічної неузгодженості інтересів між бізнесом, владою та суспільством [3]; 
- пріоритетність промисловості та сільського господарства у використанні земельних ресурсів призвела до збідніння та деградації багатьох природних рекреаційних ресурсів через надмірне антропогенне навантаження на них [19].

Пошук шляхів розвитку рекреаційного природокористування потребує забезпечення ефективного використання природних ресурсів (зокрема, лікувальних, рекреаційно-туристичних тощо) та їх диверсифікації через удосконалення нормативно-правового та організаційного забезпечення 3 урахуванням таких критеріїв, як відносини власності на природні рекреаційно-туристичні ресурси, їх форми та види, можливість диверсифікації їх використання, збалансованість соціо-економіко-екологічних інтересів та інклюзивність.

\section{Розділ 2. Аналіз нормативно-правового та організаційного забезпечення процесів використання природних ресурсів}

Концепція ощадливого використання природних ресурсів пройшла довгий шлях свого становлення як на світовому рівні, так i на національному. Еволюція поглядів щодо ресурсозбереження в контексті обмеженості світового природно-ресурсного потенціалу почалася ще 3 перших заходів Програми ООН щодо навколишнього середовища: збалансований розвиток (1972 р.), сталий розвиток (1992 р. - Порядок денний на XXI століття, 1997 р. - Pio+5, 2012 - Pio+20, 2002 p. Всесвітній саміт у Йоганнесбурзі, 2015 р. - Цілі сталого розвитку), «зелена» економіка, заходи із запобігання наслідкам зміни клімату, інклюзивний сталий розвиток. Поштовхом для формування ощадливого ставлення до природного капіталу стали численні міжнародні документи, присвячені створенню дієвих заходів, здатних призупинити збідніння населення й «одночасно сприяти створенню гідних робочих місць, чистої енергетики та раціональнішого і справедливого використання природних ресурсів» [20]. Урахування екологічного складника стає своєрідним іміджевим показником сучасної інноваційної країни, надійного інвестиційного партнера, привабливої туристичної дестинації [21].

Фахівці Міжнародного банку реконструкції і розвитку на прикладі Євразії пропонують у вигляді оптимального використання природних ресурсів запровадити диверсифікацію їх використання. Зокрема, пропонується урядам використовувати ресурсну ренту для здійснення інвестицій в освіту та інфраструктуру поряд 3 ужиттям заходів, спрямованих на вдосконалення системи регулювання приватного підприємництва. У разі належного застосування такого підходу можна поліпшити економічні показники: стабілізувати економіку, збільшити зайнятість і підвищити продуктивність, як результат, подальша диверсифікація економіки, що забезпечуватиме більш диверсифікований розвиток [22]. 
Чинна нормативно-законодавча база 3 погляду сприяння процесам екологізації соціально-економічного розвитку поділяе нормативнозаконодавчі документи на такі категорії [23]: акти, що визначають національні пріоритети, соціально-економічного та екологічного розвитку держави загалом; акти, що регулюють екологічну безпеку, підтримують технологічний розвиток та сприяють упровадженню в економічну діяльність засад раціонального використання природних ресурсів; акти, що безпосередньо спрямовані на дотримання екологічної безпеки, охорону, раціональне використання і відтворення природних ресурсів.

Серед цих основних документів - Конституція України, закони України, постанови ВР України, державні стратегії та ін. Аналіз інституційної бази щодо розвитку рекреаційно-туристичної діяльності та використання природних ресурсів різних форм та прав власності вказує на таке. Для забезпечення альтернативного розвитку рекреаційнотуристичної інфраструктури (транспорт, зв язок, комунальне господарство) необхідно розв язати низку територіальних, соціальноекономічних, екологічних викликів i завдань щодо використання природних рекреаційних ресурсів і визначення шляхів збалансування міжгалузевих інтересів.

Розглянемо інституційні засади щодо державного управління природними рекреаційними ресурсами на основі розвитку рекреаційнотуристичної діяльності та форм і прав власності у цій сфері. Основними елементами сучасної організаційно-управлінської системи природокористування та рекреаційно-туристичної галузі вибрані для аналізу такі структури, як: Міністерство культури та інформаційної політики України; Міністерство аграрної політики та продовольства України; Міністерство захисту довкілля та природних ресурсів України; Державне агентство водних ресурсів України; Державне агентство України з управління зоною відчуження; Державна служба геології та надр України; Державна екологічна інспекція України; Державна служба України з питань геодезії, картографії та кадастру; Державне агентство лісових ресурсів України; Державне агентство рибного господарства України; Державне агентство розвитку туризму України [24].

За результатами проведеного аналізу положень установчих документів зазначених виконавчих органів ми дійшли такого висновку. Позитивним фактором $є$ наявність державних органів виконавчої влади та місцевих органів самоуправління, що намагаються здійснювати регулювання розвитку рекреації та туризму. Негативним моментом $\epsilon$ те, що їхня діяльність здійснюється без необхідної для цього державної підтримки та виділення з різних джерел та бюджетів необхідних коштів для проведення заходів щодо розвитку туризму та рекреації, відтворення природних ресурсів, що експлуатуються [25]. 
Проте треба зазначити, що жоден 3 органів управління у сфері природокористування не фіксує у своїх завданнях необхідність здійснення єдиної державної політики в галузі розвитку ринкових відносин щодо певних форм та прав власності на природні ресурси і відповідних обмежень у формах, правах та суб`єктах власності. Обов'язковою умовою ефективного управління використанням $\epsilon$ визначення переліку природних ресурсів, які повинні знаходитися тільки y державній власності i використовуватися лише державними підприємствами, та природних ресурсів, що можуть знаходитися у будьякій формі власності. Усі організаційні структури сфери природокористування ставлять завдання щодо загальнодержавного використання природних ресурсів, але не визначаються завдання щодо функціонування та доцільності зміни форм використання природних об'єктів, визначення соціо-економіко-екологічних обмежень форм власності з метою захисту інтересів народу за зміни форм привласнення природних об'єктів.

На основі дослідження сучасної системи регулювання використання природних рекреаційних ресурсів та проблем розвитку відносин власності пропонується вдосконалення сукупності функцій управління природними рекреаційними ресурсами виконавчими органами влади щодо розвитку відповідного сектору національної економіки як передумови диверсифікації використання природних ресурсів, а саме:

- актуалізація державних стратегічних документів щодо розвитку форм та прав власності на природні рекреаційні ресурси - для визначення категорій ресурсів, що знаходитимуться тільки в державній власності, та тих, що можуть перебувати в інших формах власності та використовуватися різними суб`єктами господарської діяльності для запобігання створенню соціо-економіко-екологічних конфліктів між ними;

- удосконалення нормативно-правової бази щодо реалізації форм та прав власності на природні рекреаційні ресурси;

- розвиток договірних відносин, що виникають між основним розпорядником та власником природних ресурсів в умовах різноманіття прав власності та під час передачі природних ресурсів у власність або у користування;

- удосконалення системи природно-ресурсних платежів за використання природних рекреаційних ресурсів як складової частини національного багатства народу України;

- мотивація природокористувачів до залучення в господарський обіг природних рекреаційних ресурсів;

- мінімізація трансакцій щодо: участі держави під час передачі у власність природних рекреаційних ресурсів; контролю над використанням природних рекреаційних ресурсів відповідно до права власності, специфіки форм і прав власності на них та інститутів як організацій, що здійснюють управління та контроль; 
- формування, запровадження, реалізація та контроль системи соціальних, економічних та екологічних обмежень щодо використання природних рекреаційних ресурсів за будь-яких форм та прав власності на них;

- формування та запровадження системи нормативів забруднення та лімітів споживання рекреаційних природних ресурсів рекреаційнотуристичною сферою та іншими секторами економіки, що впливають на природні рекреаційні об'єкти;

- удосконалення інструментарію формування та використання кадастрової інформації щодо рекреаційних територій та ресурсів як екосистемної сукупності рекреаційних та інших природних ресурсів;

- формування та запровадження системи економічного та економікоекологічного моніторингу стану природних та техногенних рекреаційних ресурсів та субєктів їх власності, виконання ними обмежень та обтяжень у використанні природних ресурсів;

- формування організаційних механізмів доступу громадськості до оцінки напрямів використання природних рекреаційних ресурсів, шляхів їх здійснення, контролю над проведенням торгів, аукціонів щодо природних ресурсів, зміни форм, прав та суб єктів власності [26].

На тлі перелічених проблем щодо регулювання відносин власності на природні рекреаційні ресурси відкритими також $\epsilon$ питання щодо узгодження соціо-економіко-екологічних інтересів у межах господарювання на регіональному та територіальному рівнях. Важливим у цьому аспекті $\epsilon$ питання розвитку дозвільної системи у сфері використання природних ресурсів та встановлення відповідних обмежень з урахуванням форм та прав власності на них.

\section{Розділ 3. Інструменти регулювання процесів диверсифікації використання природних рекреаційних ресурсів}

Користувачами природних рекреаційних ресурсів зазвичай виступають фізичні особи, тоді як за регулювання їх використання відповідають державні органи. Тобто в процесі їх взаємодії виникають конфлікти інтересів, зокрема: отримання позитивного економічного ефекту, добрий стан навколишнього середовища та потреби всіх верств населення. Відповідно до ст. 13 Конституції України [27], «земля, іiі надра, атмосферне повітря, водні та інші природні ресурси ... $є$ об'єктами права власності Українського народу. ... розпорядження ними здійснюють органи державної влади та органи місцевого самоврядування в межах, визначених цією Конституцією».

Соціо-економіко-екологічний інтерес суб'єктів власності у використанні природних рекреаційних ресурсів - форма виявлення потреби у: наявності сприятливих для оздоровлення, відпочинку та лікування природних ресурсів; доступності їх використання фізичними та юридичними особами у рекреаційній сфері; розвитку ефективного 
підприємництва для одержання доходу від використання природних рекреаційних ресурсів, зменшення забруднення і виснаження власного рекреаційного ресурсу та мінімізації негативного впливу на нього інших суб’єктів господарювання.

До основних принципів узгодження інтересів використання природних рекреаційних ресурсів належать: альтернативність використання природних рекреаційних ресурсів шляхом державного планування їх розподілу за напрямами діяльності та формами власності; мінімізація ірраціональних управлінських рішень щодо привласнення природних рекреаційних ресурсів; превентивність зниження ризиків виробничої діяльності щодо забруднення природних рекреаційних ресурсів; створення економічних та інституційних умов досягнення балансу інтересів різних верств населення щодо використання природних рекреаційних ресурсів [28].

Тобто, як свідчить нормативно-правова база, сфера використання рекреаційних ресурсів, з одного боку, чітко не виокремлена, а 3 іншого контролюється цілою низкою різноманітних документів i, як наслідок, значно зменшує ефективність їх використання у цій галузі. У частині недосконалості організаційної системи управління прикладом виступає підпорядкування різних рекреаційних ресурсів до компетенції різних відомств.

Отже, для подолання соціо-економіко-екологічного конфлікту необхідно вносити зміни до нормативно-правової бази щодо використання (привласнення) природних рекреаційних ресурсів, у частині закріплення економічно доцільних, соціально виправданих відносин власності, які забезпечать екологобезпечне, збалансоване використання рекреаційних ресурсів в інтересах суспільства та окремого індивідуума. Треба зауважити, що в основі будь-якого конфлікту первинними $\epsilon$ економічні інтереси щодо відносин використання природних ресурсів, зокрема рекреаційних [29].

Обмеженість природних рекреаційних ресурсів, їх екосистемність та поліфункціональність визначають необхідність із боку органів управління проведення диверсифікації видів діяльності (не завжди рекреаційної) на основі встановлення різних рівнів запасів природних рекреаційних ресурсів, їх забруднення та обчислення величини завданих збитків щодо якості цих ресурсів [30].

Дозвільна діяльність має проводитися з урахуванням інтересів усіх власників природних ресурсів i спрямовуватися на захист загальнонародних інтересів та інтересів кожного суб'єкта економіки, запобігання наданню дозволів на заздалегідь завищені обсяги викидів, скидів та розміщення відходів.

Метою дозвільної та ліцензійної діяльності $€$ забезпечення використання в рекреаційних територіях та в територіях, що знаходяться поблизу рекреаційних, такого устаткування та технологій, рівень яких 
відповідає асиміляційному потенціалу рекреаційної території, не погіршує існуюче на неї навантаження та не призводить до конфлікту інтересів власників та користувачів природних ресурсів.

Необхідно на законодавчому рівні прописати процедуру звернення домогосподарств, фізичних осіб, громадських організацій до екологічних інспекцій, спеціально уповноважених державних структур за фіксації ними понадлімітних викидів, скидів, розміщення відходів на несанкціонованих звалищах.

Для формування ефективної дозвільної системи в природокористуванні та наданні ефективних адміністративних послуг із боку державних органів виконавчої влади особам звернення необхідно об`єднати в одну систему всю інформацію щодо використання природних ресурсів фізичною чи юридичною особою. Кожний підприємець чи домогосподарство повинні мати «історію природокористування», що фіксується у спеціальному реєстрі. Дозвільна система має включати не лише видачу дозволу на використання певного природного ресурсу, а й необхідно проводити контроль над його використанням і здійснювати заходи щодо штрафних санкцій, анулювання дозволу у разі невиконання його умов. Це необхідно для того, щоб за повторного одержання дозволу вся історія природокористування була зафіксована, і орган, що його видає, міг проаналізувати відповідність використання природного ресурсу умовам попереднього дозволу [31].

Процес видачі дозволів у сфері природокористування значний проміжок часу регламентувався винятково природоресурсними кодексами i законами. Основним із них є Закон України «Про дозвільну систему у сфері господарської діяльності» [32], в якому визначено дозвільні механізми в природокористуванні та їх організаційно-правові засади функціонування. Зазначений Закон та суміжні до нього інші нормативноправові акти сформували узагальнені вимоги процесу видачі документів дозвільного характеру та сприяли узгодженню норм поресурсного природокористування та підзаконних актів. Проте ідея уніфікації, яка була покладена в основу законодавчих документів для забезпечення єдності підходів до процесу видачі дозволів, не була реалізована належним чином і не досягла очікуваних результатів. Серед позитивних досягнень слід відзначити видачу дозвільних документів та надання адміністративних послуг за принципом «єдиного вікна», водночас підстави видачі дозвільних документів не зазнали суттєвих змін [33].

Дозволи надаються Держгеонадрами на основі аукціонів або без їх проведення, також у разі видобування корисних копалин місцевого значення. Доцільність їх розроблення підтверджується відповідним рішенням ДЗК України. У «Порядку надання спеціальних дозволів на користування надрами», у пункті 10, наголошується, що невіддільною частиною дозволу $\epsilon$ угода про умови користування надрами, що укладається між органом із питань надання дозволу і надрокористувачем 
і містить програму робіт, яка оформляється як додаток, та особливі умови надрокористування. Дозвіл 3 угодою про умови користування надрами та додатками до неї підлягає опублікуванню на офіційному вебсайті органу з питань надання дозволу не пізніше ніж протягом п'яти робочих днів після їх підписання. Зразки угоди про умови користування надрами затверджуються органом із питань надання дозволу та підлягають публікації на його офіційному вебсайті [34].

Проаналізований зміст спеціальних дозволів на використання корисних копалин свідчить про певну регламентацію місця розташування, обсягів видобутку та строків експлуатації. Зазначено необхідність виконання умов органів, що відповідають за якісний стан об’єктів користування. Дозвіл установлює форму звітності підприємства перед Держгеонадрами України. За умовами дозволу за формою 5-гр (тверді горючі, металічні та неметалічні корисні копалини) (річна) «Звітний баланс запасів корисних копалин за рік») підприємство надає інформацію з видобутку корисних копалин, придатних для лікувального застосування. У графі 5 зазначеної форми наводяться дані про продукцію, яка виготовляється з корисних копалин, та ії реалізацію за такими показниками:

- номенклатура і вихід (за видами) готової продукції;

- основні споживачі;

- кількість (за видами) готової продукції, що відвантажена споживачам;

- фактична собівартість одиниці видобутку сировини;

- відпускна ціна одиниці сировини;

- відпускна ціна одиниці готової продукції.

Разом із тим форма 7-гр (підземні води) (річна) «Звітний баланс використання підземних вод за рік» не передбачає надання користувачем родовища інформації щодо економічних показників використання лікувальних вод. Дана форма фіксує геологічні показники родовища, що ускладнює аналіз обсягів товарної лікувальної води. Проте у Податковому кодексі ставки рентної плати за користування надрами для видобування корисних копалин установлюються у відсотках від вартості товарної продукції гірничого підприємства видобутої корисної копалини (мінеральної сировини), зокрема видобутої мінеральної лікувальної води встановлені у розмірі 5\% від вартості товарної продукції підприємства.

Отже, існує велика кількість прогалин щодо ведення діяльності суб єктами господарювання у сфері використання природних рекреаційних ресурсів, а саме немає чіткого зв'язку між етапами отримання ліцензії на видобуток, бальнеологічного висновку та контролю з боку держави над діяльністю природокористувачів. Усе це призвело до того, що немає єдиної бази даних щодо наявних запасів природних рекреаційних ресурсів та їх оцінки у грошовому еквіваленті. Таке становище веде до певного протиріччя між інтересами держави у 
раціональному використанні цих ресурсів та приватними суб'єктами поводження ними. Питання відносин власності на природні ресурси потребує обгрунтування щодо їх раціонального використання за різними формами та правами i, як наслідок, ускладнення форм взаємодії ринку та державного регулювання економіки, взаємозв язку малого (приватного) бізнесу й інклюзивності сфери природокористування [35]. Дуже часто цінні лікувальні природні ресурси використовуються не за їх прямим напрямом або залучаються до господарського обігу через використання територіально розташованих із ними інших природних ресурсів, що призводить до економіко-екологічних збитків цінних лікувальних природних ресурсів. Слід підкреслити, що всі природні ресурси у цілому знаходяться у різному адміністративному підпорядкуванні на різних рівнях державної влади, що призводить до безконтрольного їх видобутку та використання.

\section{Висновки}

Аналіз соціо-економіко-екологічних показників рекреаційної сфери, проведений за трьома групами чинників (соціо-економічними, медикобіологічними, природними та екологічними), указує на наявність суттєвої стратифікації населення за ознакою матеріальної забезпеченості, значення основних коефіцієнтів, що оцінюють ступінь нерівності за рівнем матеріального добробуту в суспільстві, не тільки не зменшилися, а, навпаки, зросли; свідчить про низьку купівельну спроможність більшості населення України, необхідність забезпечення його потреб в оздоровленні шляхом розширення доступності рекреаційних послуг.

Визначено, що передумовою соціо-економіко-екологічних конфліктів у використанні природних ресурсів рекреаційно-туристичної сфери $\epsilon$ економічні відносини щодо прав та форм власності на них, зокрема: значна частина основних факторів виробництва (об’єкти та основні фонди, що залучені до надання оздоровчих послуг) знаходяться у приватній власності суб'єктів підприємницької діяльності, тоді як природні рекреаційні ресурси знаходяться у власності держави та місцевих органів виконавчої влади.

Сучасний стан нормативно-правового забезпечення, законодавчих актів та інститутів природокористування i розвитку рекреаційнотуристичної сфери свідчить про те, що жоден із цих органів не фіксує у своїх завданнях необхідність здійснення єдиної державної політики у сфері розвитку відносин власності щодо використання природних рекреаційних ресурсів на основі функціонування певних форм та прав власності. Те ж саме стосується встановлення обмежень щодо форм, прав та суб'єктів власності з урахуванням соціальної значущості, унікальності природних рекреаційних ресурсів та забезпечення збереження довкілля. Не відбувається визначення на цій основі видів 
природних рекреаційних ресурсів як тих, що можуть бути тільки у державній власності та використовуватися державними підприємствами, так і тих, що можуть перебувати в інших формах і правах власності та використовуватися недержавними підприємствами.

У країні немає єдиної бази даних щодо наявних запасів природних рекреаційних ресурсів та їх оцінки у грошовому еквіваленті. Таке становище призводить до певного протиріччя між інтересами держави у раціональному використанні цих ресурсів та приватними інтересами суб'єктів поводження з ними. Різне адміністративне підпорядкування природних ресурсів на різних рівнях державної влади призводить до безконтрольного їх видобутку та використання. На тлі перелічених проблем щодо регулювання відносин власності на природні рекреаційні ресурси відкритими також $є$ питання щодо узгодження соціо-економікоекологічних інтересів у межах господарювання на регіональному та територіальному рівнях.

\section{Список використаних джерел:}

1. Туристична діяльність в Україні. Держстат Украйни. URL: http://ukrstat.gov.ua/operativ/operativ2019/tyr/tyr_dil/arch_tyr_dil.htm

2. Черчик Л.М. Ринкові трансформації у рекреаційному природокористуванні : дис. ... докт. екон. наук : 08.00 .06 ; ЛНТУ, 2007. 410 c.

3. Галаченко О.О. Регіональна політика розвитку сфери санаторно-курортних послуг : дис. ... докт. екон. наук : 08.00 .05 ; ДУ «Інститут регіональних досліджень ім. М.І. Долішнього НАН України». Львів, 2019. 479 с.

4. Андрєєва Г.П., Коваль П.Ф. Теоретичні засади спеціалізованого туризму. Глобальні та національні проблеми економіки. 2015. № 7. URL: http://global-national.in.ua/ issue-7-2015/15-vipusk-7-veresen-2015-r/1190-andreeva-g-p-koval-p-f-teoretichni-zasadispetsializovanogo-turizmu

5. Антонюк В.П. Рекреаційно-туристична сфера України як чинник людського розвитку. Збірник наукових прачь Таврійського державного агротехнологічного університету (економічні науки). 2015. № 1(29). С. 146-152.

6. Келлер К.Л. Стратегический бренд-менеджмент: создание, оценка и управление марочным капиталом / пер. с англ. ; 2-е изд. Москва : Вильямс, 2005. 436 с.

7. Корнацький В.М. Проблеми здоров'я та подовження тривалості життя населення України. Наукові дискусії. 2008. № 5(67). IX-X. URL: https://www.umj.com.ua/ article/2596/problemi-zdorov-ya-ta-podovzhennya-trivalosti-zhittya-naselennya-ukraini

8. Котенко Т.М., Каленюк І.С. Соціальні аспекти розвитку рекреації і туризму як значущого сегменту світового господарства: теоретико-методологічні засади. Науковий вісник УжНУ. 2015. Вип. 3. С. 172-176.

9. Нездоймінов С.Г. Туризм як фактор регіонального розвитку: методологічний аспект та практичний досвід : монографія. Одеса : Астропринт, 2009. 304 c.

10. Нездоймінов С.Г. Сучасний стан розвитку санаторно-курортних закладів. Оиінка туристично-рекреаційного потенціалу регіону / за заг. ред. В.Г. Герасіменко. Одеса : ОНЕУ, 2016. С. 197-215.

11. Прогнімак О.Д. Інклюзивний розвиток України: перешкоди vs перспективи. Економічний вісник Донбасу. 2018. № 1(51). C. 187-197. URL: http://www.evdjournal.org/ download/2018/1(51)/pdf/26-Prohnimak.pdf 
12. Соціальний потенціал сталого розвитку: інноваційні механізми формування та використання / O.I. Амоша та ін. Донецьк : Ін-т економіки пром-ті НАН України, 2014. 477 c.

13. Хумарова Н.І. Вдосконалення системи управління рекреаційно-туристичною діяльністю на основі інклюзивного підходу. Теорія та практика менеджменту безпеки : матеріали Міжнар. наук.-практ. конф., 18 травня 2017 р. / відп. ред. проф. Л.М. Черчик. Луцьк, 2017. С. 166-168.

14. Цілі сталого розвитку: Україна. Національна доповідь / Міністерство економічного розвитку і торгівлі України. 2017. URL: http://www.ua.undp.org/ content/ukraine/uk/home/library/sustainable-development-report/sustainable-developmentgoals--2017-basseline-nationalreport.html

15. Черчик Л.М. Маркетинг рекреаційних територій : монографія. Луцьк : ЛДТУ, 2006. $136 \mathrm{c.}$

16. Черчик Л.М., Милько І.П. Механізм формування та регулювання міжгалузевих зв'язків у рекреаційному комплексі регіону. Луцьк : ЛНТУ, 2012. 160 с.

17. Черчик Л.М., Шубала I.В., Срмейчук А.І. Теоретичні основи кадрового забезпечення туристично-рекреаційної сфери. Економічні науки. Серія «Економічна теорія та економічна історія». 2012. Вип. 9(36). С. 325-341.

18. Чир Н.В. Рекреаційна географія : навчально-методичний посібник. Мукачево : Дишкант С.Я., 2019. 156 с.

19. Балацький О.Ф., Петрушенко М.М., Шевченко Г.М. Конфліктна складова системи соціоприродних зв'язків в економічній сфері взаємовідносин. Механізм регулювання економіки. 2012. № 2. C. 140-153. URL: https://mer.fem.sumdu.edu.ua/ content/acticles/issue_10/O_F_Balatskyy_M_M_Petrushenko_G_M_ShevchenkoThe_cate gory_of_social_and_natural_conflicts_in_economic_system.pd

20. Етапи виникнення та становлення концепції сталого розвитку. Сталий розвиток для України : сайт. URL: https://sd4ua.org/shho-take-stalij-rozvitok/istoriya/

21. Голікова О.С. Аналіз світового досвіду використання природних рекреаційних ресурсів і територій. Домінанти сталого розвитку регіонів України : монографія. Одеса : ІПРЕЕД НАНУ, 2020. С. 496-505.

22. Диверсифицированное развитие оптимальное использование природных ресурсов в регионе Евразии / И. Гилл и др. International Bank for Reconstruction and Development, The World Bank. URL: https://www.worldbank.org/content/dam/ Worldbank/Feature\%20Story/ECA/diversified-development-eurasia-overview-russian.pdf

23. Property management dominants for recreational natural resources / B. Burkynskyi et al. Економіка. Екологія. Соиіум. 2018. № 2. C. 77-90. URL: https://ees-journal.com/ index.php/journal/article/view/87/51

24. Про внесення змін до Закону України «Про туризм» : Закон України від 18.11.2003 № 1282-IV. Законодавство України : вебсайт. URL: http://zakon4.rada.gov.ua/ laws/show/1282-15

25. Інші органи виконавчої влади : вебсайт. URL: https://www.kmu.gov.ua/catalog

26. Буркинський Б.В., Хумарова Н.І. Наукові засади управління власністю на рекреаційні природні ресурси України. Економіка: реалї̈ часу. 2018. № 5(39). C. 5-13. URL: https://economics.opu.ua/files/archive/2018/No5/5.pdf

27. Конституція України : Закон України від 28.06.1996 № 254к/96-ВР (зі змінами від 01.01.2020 № 27-IX). Законодавство України : вебсайт. URL: https://zakon.rada.gov.ua/laws/show/254к/96-вp\#Text

28. Analysis of the touristic recreational potential of a territory as a condition for development of ecological tourism (the Southern Moscow Region Case Study) / V.J. Ivlev et al. Journal of Environmental Management and Tourism. 2017. Vol. 8. P. 373-384. DOI:10.14505/jemt.v8.2(18).10 
29. Мартієнко А.І., Тютюнник Г.О. Інституційні аспекти розвитку відносин власності на природні рекреаційно-туристичні ресурси прибережних територій. Економічні інновації. 2018. Вип. 66. С. 120-127.

30. Мартієнко А.І. Методологічні основи реалізації відносин власності на природні рекреаційно-туристичні ресурси. Економічні інноващії. 2016. Вип. 62. C. 193-199.

31. Теоретико-методологічні засади формування менеджменту відносин власності на природні рекреаційні ресурси / Б.В. Буркинський та ін. Одеса : ІПРЕЕД НАНУ, 2019. 249 c.

32. Про дозвільну систему у господарській діяльності : Закон України від 06 вересня 2005 р. № 2806-IV. Відомості Верховної Ради України. 2005. № 48. Ст. 483.

33. Про Перелік документів дозвільного характеру у сфері господарської діяльності : Закон України від 19 травня 2011 р. № 3392-VI. Голос Украӥни. 2011. № 108.

34. Державна служба України 3 питань геодезії, картографії та кадастру. URL: https://land.gov.ua/

35. Мартієнко A.I., Хумарова H.I. Економіка природокористування: адміністративне управління. Одеса : ІПРЕЕД НАНУ, 2017. 300 с.

\section{References:}

1. State Statistics Service of Ukraine (2019) Tourist activity in Ukraine. Available at: http://ukrstat.gov.ua/operativ/operativ2019/tyr/tyr_dil/arch_tyr_dil.htm

2. Cherchyk L.M. (2007) Rynkovi transformatsii u rekreatsiinomu pryrodokorystuvanni [Market transformations in recreational nature management] (PhD Thesis), Lutsk State Technical University.

3. Halachenko O.O. (2019) Rehionalna polityka rozvytku sfery sanatorno-kurortnykh posluh [Regional policy of development of the sphere of sanatorium-resort services] (PhD Thesis), Lviv: State Institution «Institute of Regional Studies named after E. Dolishny NAS of Ukraine».

4. Andreeva G.P., Koval P.F. (2015) Teoretychni zasady spetsializovanoho turyzmu [Theoretical principles of specialized tourism]. Global and national economic problems, no. 7. Available at: http://global-national.in.ua/issue-7-2015/15-vipusk-7-veresen-2015r/1190-andreeva-gp-koval-pf-teoretichni-zasadi -specialized-tourism

5. Antonyuk V.P. (2015) Rekreatsiino-turystychna sfera Ukrainy yak chynnyk liudskoho rozvytku [Recreational and tourist sphere of Ukraine as a factor of human development]. Collection of scientific works of the Tavriya State Agrotechnological University (economic sciences), no. 1(29), pp. 146-152.

6. Keller K.L. (2005) Strategicheskiy brend-menedzhment: sozdanie, otsenka i upravlenie marochnym kapitalom [Strategic brand management creation, evaluation and management of brand capital]. Moscow: Williams Publishing House. (in Russian)

7. Kornatsky V.M. (2008) Problemy zdorovia ta podovzhennia tryvalosti zhyttia naselennia Ukrainy [Health problems and life expectancy in Ukraine]. Scientific discussions, no. 5(67), IX-X. Available at: https://www.umj.com.ua/article/2596/problemizdorov-ya-ta-podovzhennya-trivalosti-zhittya-naselennya-ukraini

8. Kotenko T.M., Kalenyuk I.S. (2015) Sotsialni aspekty rozvytku rekreatsii i turyzmu yak znachushchoho sehmentu svitovoho hospodarstva: teoretyko-metodolohichni zasady [Social aspects of recreation and tourism development as a significant segment of the world economy: theoretical and methodological principles]. Scientific Bulletin of Uzh NU, no. 3, pp. 172-176.

9. Nezdoiminov S.G. (2009) Turyzm yak faktor rehionalnoho rozvytku: metodolohichnyi aspekt ta praktychnyi dosvid [Tourism as a factor of regional 
development: methodological aspect and practical experience]. Odessa: Astroprint. (in Ukrainian)

10. Nezdoiminov S.G. (2016) Suchasnyi stan rozvytku sanatorno-kurortnykh zakladiv [The current state of development of sanatoriums]. Assessment of the tourist and recreational potential of the region, Odessa: ONEU. pp. 197-215.

11. Prognimak O.D. (2018) Inkliuzyvnyi rozvytok Ukrainy: pereshkody vs perspektyvy [Inclusive development of Ukraine: obstacles vs prospects]. Economic Bulletin of Donbass, no. 1(51), pp. 187-197.

12. Amosha O.I., Novikova O.F., Antonyuk V.P. etc. (2014) Sotsialnyi potentsial staloho rozvytku: innovatsiini mekhanizmy formuvannia ta vykorystannia [Social potential of sustainable development: innovative mechanisms of formation and use]. Donetsk: Institute of Industrial Economics of the National Academy of Sciences of Ukraine. (in Ukrainian)

13. Khumarova N.I. (2017) Vdoskonalennia systemy upravlinnia rekreatsiinoturystychnoiu diialnistiu na osnovi inkliuzyvnoho pidkhodu [Improving the management system of recreational and tourist activities on the basis of an inclusive approach]. Proceedings of the Theory and practice of security management: International. scientificpractical conference (Ukraine, Lutsk, May 18, 2017). Lutsk, pp. 166-168.

14. Ministry of Economic Development and Trade of Ukraine (2017) Sustainable Development Goals: Ukraine. National Report. Available at: http://www.ua.undp.org/ content/ukraine/uk/home/library/sustainable-development-report/sustainable-developmentgoals-2017-basseline-nationalreport.html

15. Cherchyk L.M. (2006) Marketynh rekreatsiinykh terytorii [Marketing of recreational area]. Lutsk: LSTU. (in Ukrainian)

16. Cherchyk L.M., Milko I.P. (2012) Mekhanizm formuvannia ta rehuliuvannia mizhhaluzevykh zviazkiv u rekreatsiinomu kompleksi rehionu [The mechanism of formation and regulation of intersectoral relations in the recreational complex of the region]. Lutsk: Lutsk NTU. (in Ukrainian)

17. Cherchyk L.M., Shubala I.V., Yermeychuk A.I. (2012) Teoretychni osnovy kadrovoho zabezpechennia turystychno-rekreatsiinoi sfery [Theoretical foundations of staffing tourism and recreation]. Economic sciences. Series «Economic Theory and Economic History», no. 9(36), pp. 325-341.

18. Chir N.V. (2019) Rekreatsiina heohrafiia [Recreational geography]. Mukachevo: Dishkant S.Ya. (in Ukrainian)

19. Balatsky O.F., Petrushenko M.M., Shevchenko G.M. (2012) Konfliktna skladova systemy sotsiopryrodnykh zviazkiv v ekonomichnii sferi vzaiemovidnosyn [Conflicting component of the system of socio-natural relations in the economic sphere of relations]. The mechanism of economic regulation, no. 2, pp. 140-153. Available at: https://mer.fem.sumdu.edu.ua/content/acticles/issue_10/O_F_Balatskyy_M_M_Petrushenko_ G_M_ShevchenkoThe_category_of_social_and_natural_conflicts_in_economic_system.pdf

20. Sustainable development for Ukraine (n.d.). Stages of emergence and formation of the concept of sustainable development. Available at: https://sd4ua.org/shho-take-stalijrozvitok/istoriya/

21. Golikova O.S. (2020) Analiz svitovoho dosvidu vykorystannia pryrodnykh rekreatsiinykh resursiv i terytorii [Analysis of world experience in the use of natural recreational resources and territories]. Dominants of sustainable development of the regions of Ukraine. Odessa: IPREED NASU, pp. 496-505.

22. Gill I., Izvorsky I., van Eichen W., De Rosa D. (2014) Diversified development, optimal use of natural resources in the Eurasian region. International Bank for Reconstruction and Development, The World Bank. Available at: 
https://www.worldbank.org/content/dam/Worldbank/Feature\%20Story/ECA/diversifieddevelopment-eurasia-overview-russian.pdf

23. Burkynskyi B., Martienko A., Khumarova N., Prokopiuk A. (2018) Property management dominants for recreational natural resources. Economy. Ecology. Socium, no. 2, pp. 77-90. Available at: https://ees-journal.com/index.php/journal/article/view/87/51

24. Legislation of Ukraine (2003) Law of Ukraine On Amendments to the Law of Ukraine «On Tourism» of November 18, 2003 № 1282-IV. Available at: http://zakon4.rada.gov.ua/laws/show/1282-15

25. Other executive bodies (2020). Available at: https://www.kmu.gov.ua/catalog

26. Burkinsky B.V., Khumarova N.I. (2018) Naukovi zasady upravlinnia vlasnistiu na rekreatsiini pryrodni resursy Ukrainy [Scientific principles of property management for recreational natural resources of Ukraine]. Economy: the realities of time, no. 5(39), pp. 5-13. Available at: https://economics.opu.ua/files/archive/2018/No5/5.pdf

27. Legislation of Ukraine (n.d.). Constitution of Ukraine: Law of Ukraine of 28.06.1996 № 254k/96-VR (as amended on 01.01.2020 № 27-IX). Available at: https://zakon.rada.gov.ua/laws/show/254к/96-вр\#Text

28. Ivlev V. J., Ivleva M. I., Panyukov A. I., Zulfugarzade T. E. (2017) Analysis of the tourist recreational potential of a territory as a condition for the development of ecological tourism (the Southern Moscow Region Case Study). Journal of Environmental Management and Tourism, vol. 8, pp. 373-384. DOI: 10.14505/jemt.v8.2(18).10

29. Martienko A.I., Tiutiunnyk G.O. (2018) Instytutsiini aspekty rozvytku vidnosyn vlasnosti na pryrodni rekreatsiino-turystychni resursy pryberezhnykh terytorii [Institutional aspects of the development of property relations for natural recreational and tourist resources of coastal areas]. Economic innovations, no. 66, pp. 120-127.

30. Martienko A.I. (2016) Metodolohichni osnovy realizatsii vidnosyn vlasnosti na pryrodni rekreatsiino-turystychni resursy [Methodological bases of realization of property relations on natural recreational and tourist resources]. Economic innovations, no. 62, pp. 193-199.

31. Burkinsky B.V., Khumarova N.I., Martienko A.I. (ed.) (2019) Teoretykometodolohichni zasady formuvannia menedzhmentu vidnosyn vlasnosti na pryrodni rekreatsiini resursy [Theoretical and methodological principles of formation of property relations management for natural recreational resources]. Odessa: IPREED NASU. (in Ukrainian)

32. Law of Ukraine On the permit system in economic activity of September 6, 2005 № 2806-IV. Herald of the Verkhovna Rada of Ukraine. 2005. № 48, Dec. 2. St. 483.

33. Law of Ukraine On the List of Permitting Documents in the Sphere of Economic Activity of May 19, 2011 № 3392-VI. Voice of Ukraine. 2011. № 108, 16 June.

34. State Service of Ukraine for Geodesy, Cartography and Cadastre. Available at: https://land.gov.ua/

35. Martienko A.I., Khumarova N.I. (2017) Ekonomika pryrodokorystuvannia: administratyvne upravlinnia [Economics of nature management: administrative management]. Odessa: IPREED NASU. (in Ukrainian) 